\title{
Penerapan Backward Chainning Pada Sistem Pakar Untuk Mengidentifikasi Penyakit Tanaman Padi
}

\author{
Fathin sophostac ${ }^{1}$, Johanes Pratama ${ }^{2}$, Mochamad Akbar ${ }^{3}$, M Yoga Pratama $^{4}$, Taufik Agung Pramana ${ }^{5}$, \\ Nur Arif Taufik 6 \\ 1 Universitas Adhirajasa Reswara Sanjaya \\ Jl.Sekolah Internasional No.1-2 Antapani, Bandung 40282 \\ Corresponding author's e-mail: Fathinsophostac@ars.ac.id, Johanespratama@ars.ac.id, \\ Mochamadakbar@ars,ac.id, Myogapratama@ars.ac.id, Taufikagungpraman@ars.ac.id, \\ Nurariftaufik@ars.ac.id
}

\begin{abstract}
Abstrak - Padi merupakan salah satu komoditi pangan utama di Indonesia. Kebutuhan akan komoditi padi terus meningkat dari tahun ke tahun baik sebagai bahan pangan utama, pakan ternak maupun sebagai bahan baku industri skala besar hingga skala kecil. Berbagai upaya telah dilakukan untuk meningkatkan produksi padi nasional antara lain dengan penelitian varietas unggul, perluasan areal tanam, dan penyuluhan. Namun dalam proses penanaman padi terdapat beberapa kendala yaitu intensitas serangan hama dan penyakit, dan kurangnya tenaga penyuluh pertanian. Dalam mengatasi masalah serangan penyakit pada tanaman padi, petani padi selaku pihak yang berhubungan secara langsung pada penanaman padi perlu untuk mengetahui informasi yang cepat dan akurat terkait jenis penyakit yang menyerang. Sehingga setelah didapatkan informasi penyakitnya maka dapat segera diketahui solusi untuk mengatasi serangan penyakit tersebut. Dengan berkembangnya teknologi informasi, banyak informasi yang dapat diakses secara cepat melalui layanan internet. Kemudahan akses terhadap informasi inilah yang salah satunya dapat digunakan untuk memberikan informasi kepada petani padi tentang identifikasi penyakit. Oleh karena itu peneliti mencoba memberikan salah satu solusi yang dapat dilakukan untuk membantu petani padi dalam mengidentifikasi penyakit tanaman padi. Pada penelitian ini peneliti menerapkan teorema Bayes untuk menghitung nilai probabilitas hasil identifikasi penyakit tanaman padi. Pada pengujian sampel data gejala penyakit menunjukkan bahwa menghasilkan nilai akurasi sebesar $90 \%$
\end{abstract}

Kata kunci: Aplikasi, Sistem Pakar, PHP, Web

\section{Pendahuluan}

Tanaman Padi(bahasa latin: Oryza sativaL.) merupakan salah satu tanaman budidaya terpenting dalam peradaban. Meskipun terutama mengacu pada jenis tanaman budidaya, padi juga digunakan untuk mengacu pada beberapa jenis dari marga (genus) yang sama, yang biasa disebut sebagai padi liar[1]. Padi diduga berasal dari India atau Indocina dan masuk ke Indonesia dibawa oleh nenek moyang yang migrasi dari daratan Asia sekitar 1500 SM[2]. Produksi padi dunia menempati urutan ketiga dari semua serealia, setelah jagung dan gandum. Namun, padi merupakan sumber karbohidrat utama bagi mayoritas penduduk dunia[3]. Penyakit tanaman adalah gangguan pada tanaman yang disebabkan oleh mikroorganisme (virus, bakteri, protozoa, jamur, tikus)[5]. Penyebaran penyakit pada tanaman padi biasanya melalui angin, air, serangga dan faktor lingkungan (suhu dan udara)[6]. Secara administratif Kecamatan Padang Laweh terletak di Kabupaten Dharmasraya, Provinsi Sumatra Barat. Menurut data yang diperoleh dari ketua kelompok tani Kecamatan Padang Laweh hampir 30\% petanimerupakan petani padi, dalam satu tahun terdapat tiga kali musim tanam[7]. Sebelumnya dalam mendiagnosa penyakit tanaman Padi, para petani biasanya mengamati melalui gejala-gejala yang nampak pada tanaman, misalnya ketika terkena penyakit fusarium mengakibatkat biji muda menjadi kecoklatan, daun terkulai, dan akar membusuk sehingga menyebabkan hasil panen yang tidak maksimal. Kendala utama dalam mendiagnosa jenis penyakit padi antara lain adalah minimnya pengetahuan petani tentang penyakit tanaman padi, keterbatasan waktu yang dimiliki para petani serta pengambilan keputusan pada proses penanggulangan. Sistem pakar adalah sistem berbasis komputer yang menggunakan pengetahuan, fakta, dan teknik penalaran dalam memecahkan masalah yang biasanya hanya dapat dipecahkan oleh pakar bidang tertentu[8]. Kelebihan sistem pakar diantaranya adalah memungkinkan orang awam dapat mengerjakan pekerjaan para pakar (ahli)[13]. Sistem pakar dapat digunakan untuk menyimpan pengetahuan dan keahlian pakar.Dengan menggunakan sistem pakar para petani dapat dengan mudah mendiagnosa penyakit yang menyerang tanaman padi mereka karena sistem pakar dapat digunakan untuk menyimpan pengetahuan dan keahlian pakar, selain itu sistem pakar dapat meningkatkan kapusn/abilitas dalam menyelesaikan masalah sehingga menghemat waktu dalam pengambilan keputusan. 


\section{Metode Penelitian}

Metode rekayasa perengkat lunak yang digunakan penulis adalah metode waterfall. Secara garis besar waterfall adalah suatu proses pengembangan perangkat berututan, dimana kemajuan dipandang sebagai terus mengalir ke bawah (seperti air terjun) melewati fase-fase perencanaan, pemodelan, implementasi (konstruksi), dan pengujian[9].

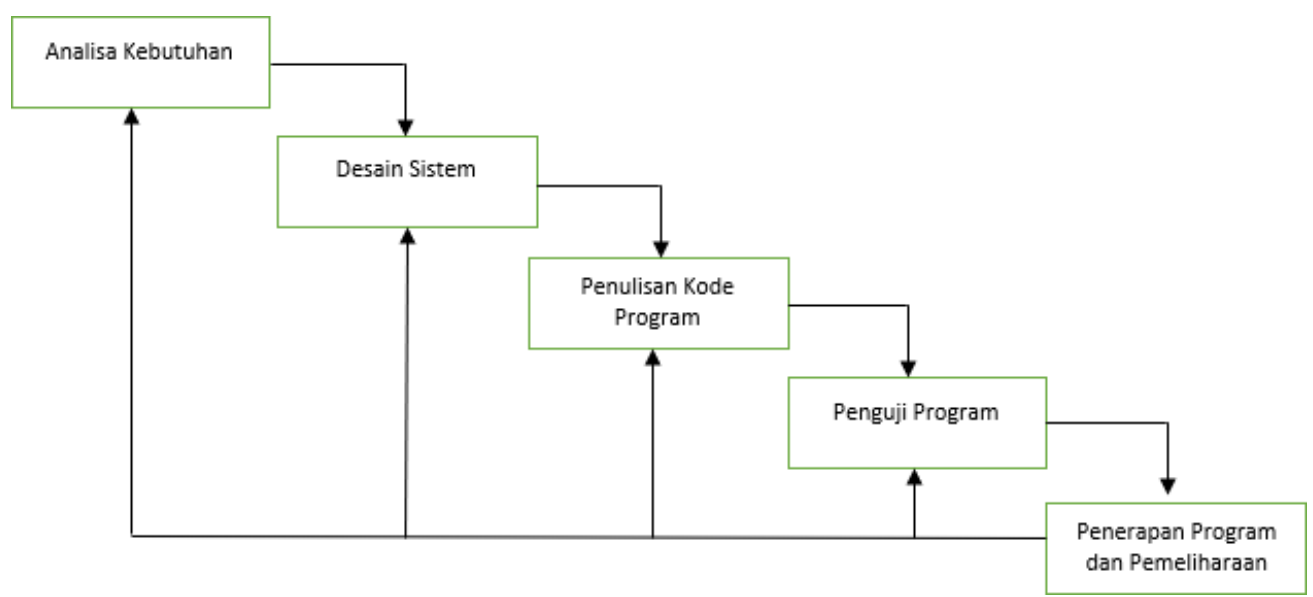

Gambar 3.1. Metode Waterfall

1.Kebutuhan

Pada proses analisa kebutuhan, yaitu peneliti membuat sebuah aplikasi pencari solusi pada penyakit tanaman padi dikarenakan selama ini petani kurang pengetahuan tentang penyakit pada tanaman padi.

2.Analisa Desain Sistem

Pada proses desain, peneliti melakukan perancangan Aplikasi yang menerima input gejala penyakit yang dialami tumbuhan padi dan memproses data setelah di input sehingga menghasilkan output solusi untuk mengatasi penyakit pada tumbuhan padi.

3.Penulisan Kode Program

Pada penulisan kode program peneliti mengunkan bahasa pemograman PHP dan menggunakan database MySQL, supaya petani bisa mengakses aplikasi dimanapun.

4.Pengujian Program

Dilanjutkan dengan proses pengujian pada program perangkat luak, pada proses pengujian ini peneliti menggunakan teknik Black Box.

5.Penerapan Program dan Pemeliharaan Penerapan Aplikasi ini akan digunakan oleh:

a.Admin (Kepala Kelompok Tani)

b.User (petani)

\section{Analisa Dan Perancangan}

Langkah dalam pembangunan sistem pakar ini adalah mengidentifikasi permasalahan yang akan dikaji, dalam hal ini dengan mengidentifikasi penyakit pada tanaman padi, adapun masalah-masalah yang akan diambil dalam pembangunan sistem pakar penyakit tanaman padi ini adalah gejala-gejala yang mengindikasi pada penyakit tanaman padi[10].

Tabel 1. Indikasi Penyakit Tanaman Padi

\begin{tabular}{|c|c|c|c|c|c|c|c|}
\hline $\begin{array}{c}\text { Penyakit } \\
\text { Gejala }\end{array}$ & $\begin{array}{c}\text { Hama Putih } \\
\text { Palsu }\end{array}$ & $\begin{array}{c}\text { Walang } \\
\text { Sangit }\end{array}$ & $\begin{array}{c}\text { Kepinding } \\
\text { Tanah }\end{array}$ & $\begin{array}{c}\text { Wereng } \\
\text { Coklat }\end{array}$ & $\begin{array}{c}\text { Penggerek } \\
\text { Batang }\end{array}$ & $\begin{array}{c}\text { Hama } \\
\text { Burung }\end{array}$ & $\begin{array}{c}\text { Hama } \\
\text { Tikus }\end{array}$ \\
\hline G1 & & $\checkmark$ & & & & & \\
\hline G2 & & $\checkmark$ & & & & & \\
\hline G3 & & $\checkmark$ & & & & & \\
\hline G4 & & $\checkmark$ & & & & & \\
\hline
\end{tabular}




\begin{tabular}{|c|c|c|c|c|c|c|c|}
\hline G5 & & $\checkmark$ & & & & & \\
\hline G6 & & & $\checkmark$ & & & & \\
\hline G7 & & & $\checkmark$ & & & & \\
\hline G8 & & $\checkmark$ & & & & & \\
\hline G9 & & & & $\checkmark$ & & & \\
\hline G10 & & & & & & $\checkmark$ & \\
\hline G11 & & & & & & $\checkmark$ & \\
\hline G12 & & & & & & & \\
\hline G13 & & & & & & & \\
\hline G14 & & & & & & & \\
\hline G15 & & & & $\checkmark$ & & & \\
\hline G16 & & & & & & & \\
\hline G17 & & & & $\checkmark$ & & & \\
\hline
\end{tabular}

Kaidah produksi dituliskan dalam bentuk IF-THEN, kaidah ini dikatakan sebagai aturan premis (jika) dan konklusi (maka), untuk masing-masing area gejala, terdapat aturan kaidah produksi gejala penyakit dalam bentuk IF-THEN rules[11] .

Tabel 2. Aturan Kaidah Produksi

\begin{tabular}{|l|l|}
\hline \multicolumn{1}{|c|}{ Nama Penyakit } & \multicolumn{1}{c|}{ Rule } \\
\hline Rule 1 : Hama Putih Palsu & $\begin{array}{l}\text { IF Daun berwarna puth AND hadir ngengat AND adanya larva THE } \\
\text { N True. }\end{array}$ \\
\hline Rule 2 : Walang Sangit & $\begin{array}{l}\text { IF Beras berubah warna AND beras mengapur AND gabah padi } \\
\text { hampa } \\
\text { THEN True. }\end{array}$ \\
\hline Rule 3 : Kepinding Tanah & $\begin{array}{l}\text { IF Tanaman berubah coklat kemerahan AND tanaman kerdil THEN T } \\
\text { rue. }\end{array}$ \\
\hline Rule 4 : Wereng Coklat & $\begin{array}{l}\text { IF Daun menguning AND daun tanaman menjadi sempit AND tanam } \\
\text { anmudah terbakar THEN True. }\end{array}$ \\
\hline Rule 5 : Pengerek Batang & IF Terdapat ulat AND tunas-tunas padi mati THEN True. \\
\hline Rule 6 : Hama Burung & $\begin{array}{l}\text { IF Biji padi banyak yang hilang AND adanya gejala beluk AND b } \\
\text { iji padihampa THEN True. }\end{array}$ \\
\hline Rule 7 : Hama Tikus & $\begin{array}{l}\text { IF Tanaman rusak hamper keseluruhan AND tengah petak sawah } \\
\text { rusak } \\
\text { THEN True. }\end{array}$ \\
\hline
\end{tabular}

Mesin inference merupakan bagian dari sistem pakar yang melakukan penalaran dengn mengunakan isi daftar rule atau aturan berdasarkan urutan dan pola tertentu yang tersimpan pada basis pengetahuan[12]. Proses inferensi menguji aturan satu demi satu sampai kondisi tersebut mencapai solusi atau kesimpulan.. Mesin inferensi mengarahkan pencarian melalui basis pengetahuan atau yang lebih disebut pencocokan pola, yang selanjutnya program kontrol memutuskan aturan mana yang akan dieksekusi.

Mekanisme inferensi pada penelitian ini mengunakan metode backward chaining yaitu teknik pencarian yang dimulai dengan hipotesa yang di ketahui, seperti dengan menentutkan nama peyakit dan kegajala yang dialamai kemudian menghasilkan fakta yang sesuai dengan hipotesa tersebut dengan bagian IF dari rules IF THEN. Bila ada hipotesa yang cocok dengan bagian IF, maka rule tersebut akan dieksekusi. Bila sebuah rule sudah dieksekusi maka sebuah fakta baru (bagian THEN) akan ditambahkan ke dalam database. Pada backward chaining pencocokan hipotesis terhadap rule, dimulai dari rule yang teratas atau yang pertama. Seperti yang di terapkan pada aplikasi ini:

1.Menentukan Penyakitnya terlebih dahulu

2.Melakuan pemilihan gejala

3.Diproses rule yang telah ditentukan

4.Menghasilkan fakta

Berikut diagram Use case sebagai berikut: 


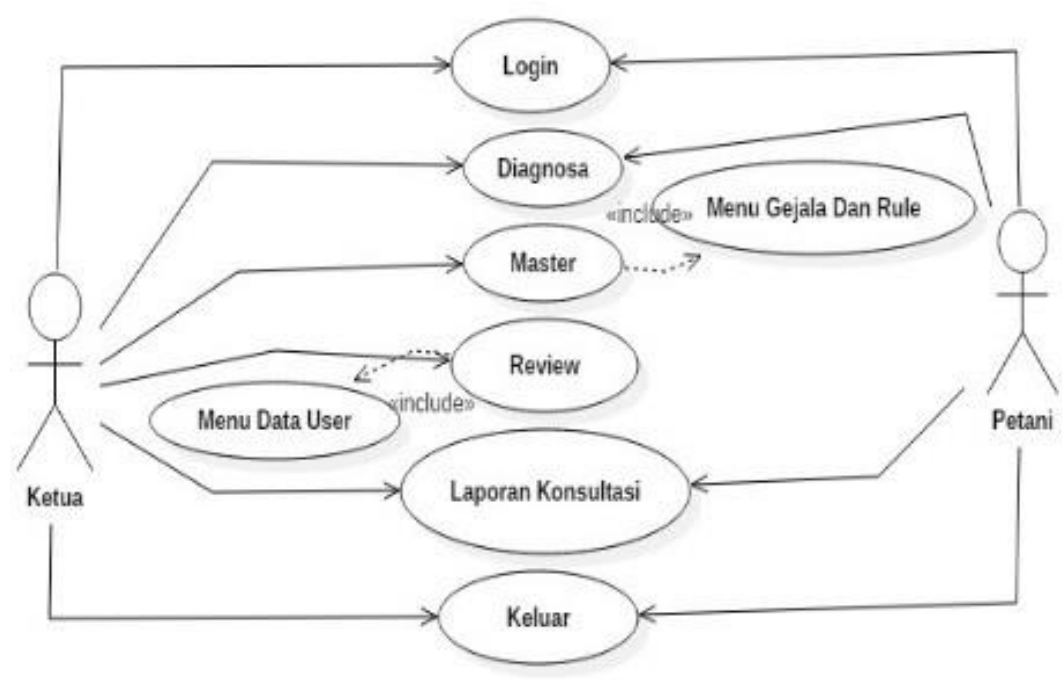

Gambar 2. Diagram Use Case

\section{Implementasi Dan Pembahasan}

Implementasi yaitu penerapan sistem yang telah dibangun di lapangan. Dimana tahapan ini menguji sistem dan menjalankan sistem sesuai dengan kebutuhan dari user, seperti pada aplikasi sistem pakar penyakit tumbuhan padi ini yang akan di tampilkan pertama kali yaitu menu login user kemudian user melakukan login dan muncul halaman menu utama. Disitu user bisa langsung klik menu diagnose untuk melakukan konsultasi penyakit yang di derita tanaman padi, setelah memilih penyakit langsung muncul menu gejala disini user harus memilih gejala yang sesuai dengan yang dialami oleh tanaman padi maka dari itu akan muncul solusi untuk mengatasi penyakit yang dialami.

\section{Kesimpulan Dan Saran}

Berdasarkan hasil penelitian pembuatan Aplikasi Penyakit Pada Tumbuhan Padi ini dapat diambil kesimpulan yaitu :

1.Aplikasi Penyakit Pada Tumbuhan Padi ini dapat memudahkan petani dalam melakukan konsultasi penyakit tanaman padi mereka dengan solusi yang diberikan oleh pakar sehingga mereka tidak perlu lagi melakukan konsultasi dengan pakar secara langsung.

2.Aplikasi Penyakit Pada Tumbuhan Padi ini dapat menyimpan pengetahuan pakar karena menggunakan database sehingga apapun pengetahuan dari pakar dapat tersimpan.

Untuk pengembang Aplikasi Penyakit Pada Tumbuhan Padi ini kedepanya, ada beberapa saran yang menjadi acuan, diantaranya adalah:

1.Aplikasi ini disarankan memiliki tampilan yang lebih baik .

2.Aplikasi ini disarankan menggunakan bahasa program android.

3.Aplikasi ini disarankan dihostingkan sehingga bisa diakses dimanapun.

\section{Daftar Pustaka}

[1]. Arhami. (2005). Konsep Dasar Sistem Pakar . Yogyakarta: Andi Offset.

[2]. Honggowibowo, A. S. (2012). Sistem Pakar Berbasis web Untuk Mendiagnosa Penyakit Tanaman Jagung dan Cara Penanggulangannya Secara Kimia Teknis. Yogyakarta: Sekolah Tinggi Teknologi Adisutjipto.

[3]. Iriani, S. (2015). Penerapan Metode Backward Chaining Pada SIstem Pakar Diagnosa Penyakit Tulang Manusia. IJNS, Volume.4 No.1 Pacitan.

[4]. Saepulloh, A., \& Fatimah. (2016). Pengembangan Sistem Pakar Diagnosa penyakit dan Hama Pada tanaman Padi Varietas Sarinah Berbasis Android. Jurnal ISSN : 2302-7339 Vol.13 No.1 2016. Garut Sekolah Tinggi Teknologi Garut.

[5]. Harahap, S., \& Tjahjono. (1989). Panyakit dan Hama Tanaman Padi. Jakarta: PT.Penebar Swadaya.

[6]. Nadal, \& Whardhana. (2006). Sistem IdentifikasiTanaman Padi. Jakarta: Dept. Pu. Diren Pengairan.

[7]. Suparyono, \& Agus, S. (2004). Mengatasimasalah Budidayapadi. Jakarta: Penebar Swadaya.

[8]. Siregar, H. (1981). Budidaya Tanaman Padi Di Indonesia. Sastra Hudaya. Jakarta: Sastra Hudaya.

[9]. Harjadi. (2008). Bercocok Tanam Padi. Bandung: M2S. 
[10]. Hartati, S., \& Sari, I. (2008). Sistem Pakar \& Pengembangannya. Yogyakarta: Graha Ilmu.

[11]. Andriani, A. (2017). Pemrograman sistem pakar. Yogyakarta: Mediakom.

[12]. Indrajani. (2018). Database Design All In One. Jakarta: Elex Media Komputindo.

[13]. A. Prasetio, "Simulasi Penerapan Metode Decision Tree (C4. 5) Pada Penentuan Status Gizi Balita," J. Nas. Komputasi dan Teknol. Inf., vol. 4, no. 3, pp. 209-214, 2021. 